\title{
A meta-analysis of cyclosporine treatment for Stevens-Johnson syndrome/toxic epidermal necrolysis
}

This article was published in the following Dove Press journal: Journal of Inflammation Research

\author{
Qin Xiang $\mathrm{Ng}^{1,2}$ \\ Michelle Lee Zhi Qing De \\ Deyn $^{3}$ \\ Nandini Venkatanarayanan ${ }^{4}$ \\ Collin Yih Xian $\mathrm{Ho}^{2}$ \\ Wee-Song Yeo ${ }^{5}$ \\ 'Department of Medicine, National \\ University Hospital, National \\ University Health System, Singapore; \\ ${ }^{2} \mathrm{MOH}$ Holdings Pte Ltd, Singapore; \\ ${ }^{3}$ Department of Medicine, James Cook \\ University Hospital, Middlesbrough, \\ UK; ${ }^{4}$ Department of Medicine, \\ Nottingham University Hospitals \\ NHS Trust, Queen's Medical Centre, \\ Nottingham, UK; ${ }^{5}$ Department of \\ Paediatrics, National University \\ Hospital, National University Health \\ System, Singapore
}

Correspondence: Qin Xiang Ng $\mathrm{MOH}$ Holdings Pte Ltd, I Maritime Square, Singapore 099253

Tel +6566220980

Email ng.qin.xiang@u.nus.edu
Background: Stevens-Johnson syndrome (SJS) and toxic epidermal necrolysis (TEN) are dermatologic emergencies with high morbidity and mortality risk. Cyclosporine, an immunomodulatory agent, is sometimes used off-label, and its role continues to be debated. This metaanalysis aimed to provide an update of current evidence and to clarify the role of cyclosporine in SJS/TEN treatment better.

Methods: Using the keywords [cyclosporine OR cyclosporine OR ciclosporin OR CsA] AND [Steven-Johnson OR SJS OR toxic epidermal OR epidermal necrolysis OR TEN OR hypersensitivity OR dermatologic OR burns], a preliminary search on the PubMed, Ovid, Web of Science, and Google Scholar Database yielded 615 papers published in English between January1, 1960 and July 1, 2017. The inclusion criteria for this review were: 1) published retrospective or prospective study (excluding single case reports); 2) patients with clinical diagnosis of SJS or TEN; 3) trial of cyclosporine treatment; and 4) available survival/mortality data.

Results: A total of 12 studies, with a total of 358 SJS/TEN patients were reviewed. Two studies were excluded from the meta-analysis as they did not report SCORe of toxic epidermal necrosis/ predicted mortality data; one was excluded because of possible data irregularities. Meta-analysis of nine studies revealed a significant reduction in mortality risk with cyclosporine therapy (standardized mortality ratio $0.320 ; 95 \% \mathrm{CI}: 0.119-0.522 ; P=0.002$ ). Cyclosporine was also generally well tolerated with little adverse effects or increased infection, albeit the patients tended to be critically ill. Publication bias was observed in the funnel plot and Egger test $(P=0.0467)$. Conclusion: Currently available evidence are predominantly open trials and retrospective studies with a significant risk of bias, perhaps owing to the rarity and life-threatening nature of the condition. Given its immunomodulatory actions, cyclosporine could be a potential treatment option for SJS/TEN in addition to best supportive measures. Further confirmation with robust randomized, controlled trials or larger case series is necessary and should be encouraged. Keywords: SJS, TEN, epidermal necrolysis, cyclosporine, CsA, meta-analysis

\section{Introduction}

Stevens-Johnson syndrome (SJS) and toxic epidermal necrolysis (TEN) are rare dermatologic emergencies with excessive morbidity and mortality risk. The incidence rate is $0.5-1.4$ per million per year, and the average mortality rate is estimated to be $25 \%-35 \%$. ${ }^{1}$ SJS and TEN are severe mucocutaneous adverse reactions, most commonly triggered by medications, including antibiotics, anticonvulsants, and nonsteroidal antiinflammatory drugs. ${ }^{2}$ SJS and TEN are considered a disease continuum and involve skin detachment of $<10 \%$ and $>30 \%$ of body surface area, respectively. ${ }^{3}$ SJS/TEN 
overlap describes patients with skin detachment of 10\%-30\% of body surface area. Patients are often critically ill and are presented with fever (prodromal) and widespread necrosis and detachment of the epidermis. ${ }^{4}$ Atypical targetoid macules appear on the skin, which eventually blister and slough off as areas of (full thickness) epidermal necrosis.

Beyond supportive care, there are no established systemic therapies for SJS and TEN. Supportive care is the cornerstone of treatment. Systemic treatment of SJS/TEN remains a matter of debate and contention. ${ }^{5}$ Several wellcharacterized human leukocyte antigen (HLA) associations, for example, HLA-B* $1502,{ }^{6}$ strongly predispose patients to specific delayed-type drug hypersensitivity reactions, including SJS/TEN. Most of the known HLA associations are class I, lending further support for the postulated role of CD8+ $\mathrm{T}$ cells in the pathogenesis of SJS/TEN. ${ }^{7}$ Adjunctive therapies include systemic corticosteroids, intravenous immune globulin (IVIg), cyclosporine (CsA), plasmapheresis, and anti-TNF monoclonal antibodies. ${ }^{8}$ All of these carry limitations, potential adverse effects, and risks.

There have been some case reports of the positive efficacy of CsA (in doses of 3-5 mg/ $\mathrm{kg} / \mathrm{d}$ ) to retard the progression of SJS/TEN and promote rapid re-epithelization. ${ }^{9-11}$ Although this is the most widely used dose, there is no consensus on its role in SJS/TEN or the appropriate duration of therapy. ${ }^{12}$

CsA is a cyclic peptide of 11 amino acids isolated from the soil fungus Tolypocladium inflatum Gams. It is hydrophobic and lipophilic and shows high interindividual and intraindividual variation in terms of pharmacokinetics. ${ }^{13}$ CsA may have an ameliorative effect in SJS/TEN patients by opposing the apoptotic pathway in nonlesional skin. ${ }^{12}$ Given its immunomodulatory actions, CsA could be a potential treatment option for SJS/TEN patients. A recent meta-analysis on systemic immunomodulating therapies for SJS and TEN analyzed only one trial pertaining to the use of CsA. ${ }^{14}$ Therefore, this meta-analytic review aims to clarify better the role of CsA in SJS/TEN treatment and generate directions for future research.

\section{Methods}

Literature search was done in accordance with preferred reporting items for systematic reviews and meta-analysis guidelines. Using the keywords [cyclosporine OR cyclosporine OR ciclosporin OR CsA] AND [Steven-Johnson OR SJS OR toxic epidermal OR epidermal necrolysis OR TEN OR hypersensitivity OR dermatologic OR burns], a preliminary search on the PubMed, Ovid, Web of Science, and Google Scholar Database yielded 615 papers published in English between January1, 1960 and July 1, 2017. Grey literature was not searched. Title/abstract screening was performed independently by (QX Ng and MLZQ De Deyn) to identify articles of interest. For relevant abstracts, full articles were obtained, reviewed, and also checked for references of interest. The authors of the articles were not contacted to provide additional data.

Full articles were obtained for all selected abstracts and reviewed by three researchers (QX Ng, MLZQ De Deyn, and $\mathrm{N}$ Venkatanarayanan) for inclusion. Any disagreement was resolved by discussion and consensus among the three researchers. The inclusion criteria for this review were: 1) published retrospective or prospective study (excluding single case reports); 2) patients with clinical diagnosis of SJS or TEN; 3) trial of CsA treatment; and 4) available survival/ mortality data. Data such as study design, study population, and demographics, SCORe of toxic epidermal necrosis (SCORTEN), a severity-of-illness score for toxic epidermal necrolysis, and outcome measure were extracted. The primary outcome measure of interest was the mortality benefit with CsA treatment. Standardized mortality ratio (SMR) of observed to the predicted number of deaths was calculated for each study. SCORTEN is a well-validated tool for predicting mortality in SJS/TEN patients. ${ }^{15,16}$ Because the normal distribution can take all real numbers (is continuous), but the binomial distribution can only take integer values (is discrete), for studies with no observed deaths, a continuity correction factor of 1 was added to both the observed and expected deaths for purposes of calculating SMR. SMRs were pooled, and where appropriate, $95 \% \mathrm{CI}$ and $P$-values were calculated.

Heterogeneity among the different studies pooled was examined using the $\mathrm{I}^{2}$ statistic and Cochran's $Q$ test. Publication bias was assessed using a funnel plot and Egger test. All analyses were done using MedCalc statistical software version 14.8.1 (MedCalc Software BVBA, Ostend, Belgium; http://www.medcalc.org; 2014) and STATA version 13.0 (STATA Corp., College Station, TX, USA).

\section{Results}

The abstraction process (and reasons for exclusion) was detailed in Figure 1. The key details of each study were extracted and summarized in Table 1. Of the 12 studies reviewed, two were excluded from the final meta-analysis as they did not report SCORTEN/predicted mortality data, and one was excluded on the basis of possible data irregularities, which may unduly affect the reliability of the meta-analysis.

With regard to the possibility of publication bias, visual inspection of the funnel plot revealed a slight asymmetrical 


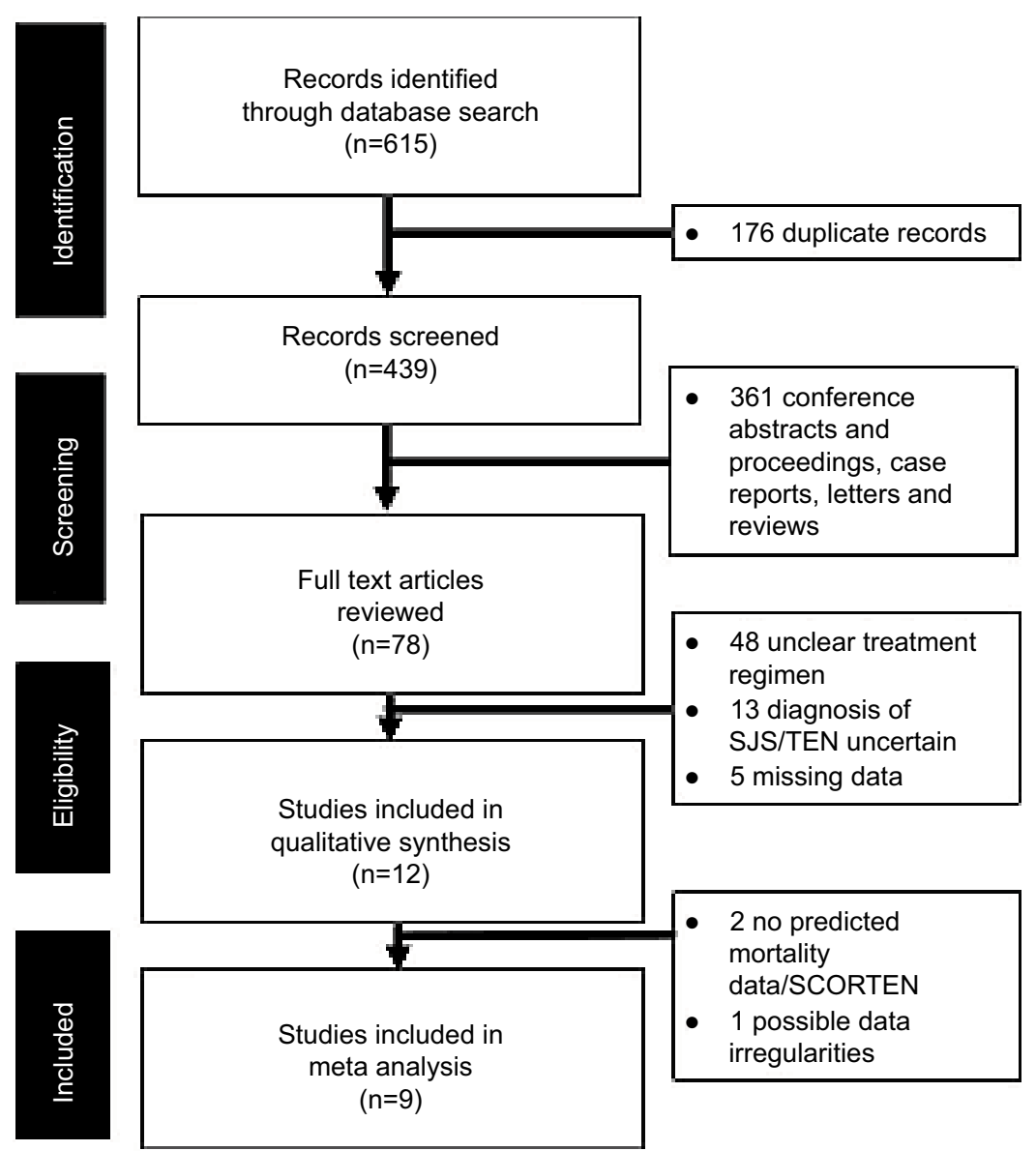

Figure I PRISMA flowchart showing the studies identified during the literature search and abstraction process.

Abbreviations: SJS, Stevens-Johnson syndrome; TEN, toxic epidermal necrolysis; SCORTEN, SCORe of toxic epidermal necrosis; PRISMA, Preferred Reporting Items for Systematic Reviews and Meta-Analyses.

Table I Characteristics of all studies included in this review

\begin{tabular}{|c|c|c|c|c|c|c|}
\hline Study & $\begin{array}{l}\text { Study } \\
\text { design }\end{array}$ & $\begin{array}{l}\text { Study } \\
\text { sample }(N)\end{array}$ & Country & $\begin{array}{l}\text { Total BSA and } \\
\text { SCORTEN }\end{array}$ & Treatment regimen $(n)$ & Conclusion \\
\hline $\begin{array}{l}\text { Arévalo } \\
\text { et al, } 2000^{17}\end{array}$ & $\begin{array}{l}\text { Retrospective } \\
\text { case series }\end{array}$ & 17 & Spain & $\begin{array}{l}\text { Mean total } \\
\text { BSA } 83 \pm 17 \% \\
\text { SCORTEN not } \\
\text { specified }\end{array}$ & $\begin{array}{l}\text { - CsA } 3 \mathrm{mg} / \mathrm{kg} / \mathrm{d} \text { enterally every } \\
12 \text { hours, for } 2 \text { weeks and then } \\
\text { tapered gradually (II) } \\
\text { - Cyclophosphamide (I50 mg IV } \\
\text { every } 12 \text { hours) and different doses } \\
\text { of corticosteroids ( } \geq 1 \mathrm{mg} / \mathrm{kg} / \mathrm{d} \text { of } \\
\text { 6-methyl-prednisolone) (6) }\end{array}$ & $\begin{array}{l}\text { CsA is safe and is associated } \\
\text { with rapid re-epithelization } \\
\text { and a lower rate of multi- } \\
\text { organ failure, severe } \\
\text { leukopenia, and death } \\
\text { than treatment with } \\
\text { cyclophosphamide and } \\
\text { corticosteroids in patients } \\
\text { with severe TEN }\end{array}$ \\
\hline $\begin{array}{l}\text { Firoz et al, } \\
2012^{18}\end{array}$ & Prospective & $82 *$ & USA & $\begin{array}{l}\text { Mean total BSA } \\
34.8 \pm 26.1 \% ; \\
\text { mean } \\
\text { SCORTEN } 2.17\end{array}$ & $\begin{array}{l}\text { - CsA (regimen not specified) only } \\
\text { used in patients with low BSA and } \\
\text { SCORTEN of 0-I (8) } \\
\text { - IVIg } 4 \mathrm{~g} / \mathrm{kg} \text { divided over } 3 \text { days if } \\
\text { patients presented within } 72 \text { hours of } \\
\text { blistering ( } 23 \text { ) } \\
\text { - Supportive care for patients who } \\
\text { presented } \geq 3 \text { days of blistering (5I) }\end{array}$ & $\begin{array}{l}\text { No significant difference } \\
\text { in survival among all three } \\
\text { treatment options ( } P=0.15 \text {, } \\
\text { log-rank test). IVlg did not } \\
\text { significantly alter mortality }\end{array}$ \\
\hline
\end{tabular}


Table I (Continued)

\begin{tabular}{|c|c|c|c|c|c|c|}
\hline Study & $\begin{array}{l}\text { Study } \\
\text { design }\end{array}$ & $\begin{array}{l}\text { Study } \\
\text { sample }(N)\end{array}$ & Country & $\begin{array}{l}\text { Total BSA and } \\
\text { SCORTEN }\end{array}$ & Treatment regimen (n) & Conclusion \\
\hline $\begin{array}{l}\text { Giudice } \\
\text { et al, } 2017^{19}\end{array}$ & $\begin{array}{l}\text { Retrospective } \\
\text { case series }\end{array}$ & 12 & Italy & $\begin{array}{l}\text { Mean total BSA } \\
76.7 \pm 12.3 \% \\
\text { mean } \\
\text { SCORTEN } 4.3\end{array}$ & $\begin{array}{l}\text { Standardized treatment protocol: CsA } \\
\text { IV } 250 \mathrm{mg} / \mathrm{d} \text { or } 4 \mathrm{mg} / \mathrm{kg} / \mathrm{d} \text { in pediatric } \\
\text { patients on day one, at day three, } \\
\text { daptomycin and plasmapheresis were } \\
\text { introduced. CsA continued for } 15 \text { days, } \\
\text { daptomycin for } 10 \text { days, plasmapheresis } \\
\text { consisted of } 7 \text { cycles spaced by } 2 \text { days } \\
\text { each (I2) }\end{array}$ & $\begin{array}{l}\text { Standardized treatment } \\
\text { protocol consisting of CsA } \\
\text { and plasmapheresis is safe and } \\
\text { efficacious in patients with } \\
\text { severe TEN }\end{array}$ \\
\hline $\begin{array}{l}\text { González- } \\
\text { Herrada } \\
\text { et al, } 2017^{20}\end{array}$ & $\begin{array}{l}\text { Retrospective } \\
\text { and } \\
\text { prospective } \\
\text { cases }\end{array}$ & 42 & Spain & $\begin{array}{l}\text { Mean total BSA } \\
43.5 \pm 26.9 \% \\
\text { mean } \\
\text { SCORTEN } 2.39\end{array}$ & $\begin{array}{l}\text { - CsA } 3 \mathrm{mg} / \mathrm{kg} / \mathrm{d} \text { until complete re- } \\
\text { epithelialization and then gradual } \\
\text { taper }(26) \\
\text { - IVIg } 0.75 \mathrm{~g} / \mathrm{kg} / \mathrm{d} \text { for } 4 \text { days }(\mathrm{II}) \\
\text { - Prednisone-equivalent } 37.5-100 \mathrm{mg} / \mathrm{d} \\
\text { for } 9-12 \text { days (2) } \\
\text { - Supportive care (3) }\end{array}$ & $\begin{array}{l}\text { CsA offers mortality benefit } \\
\text { for SJS/TEN patients }\end{array}$ \\
\hline $\begin{array}{l}\text { Kirchhof } \\
\text { et al, } 2014^{10}\end{array}$ & $\begin{array}{l}\text { Retrospective } \\
\text { case series }\end{array}$ & 64 & Canada & $\begin{array}{l}\text { Mean total BSA } \\
28.7 \pm 26.6 \% \\
\text { mean } \\
\text { SCORTEN I.65 }\end{array}$ & $\begin{array}{l}\text { - Supportive care (I2) } \\
\text { - IVIg I g/kg/d for } 3 \text { days ( } 35) \\
\text { - CsA } 3-5 \text { mg/kg/d orally or IV for an } \\
\text { average of } 7 \text { days (I5) } \\
\text { - IVlg and CsA (2) }\end{array}$ & $\begin{array}{l}\text { Relative mortality benefit of } \\
\text { CsA (SMR 0.42) over IVIg } \\
\text { (SMR I.43) in patients with } \\
\text { SJS/TEN }\end{array}$ \\
\hline $\begin{array}{l}\text { Lee et al, } \\
2017^{21}\end{array}$ & $\begin{array}{l}\text { Retrospective } \\
\text { case series }\end{array}$ & 44 & Singapore & $\begin{array}{l}\text { Mean total BSA } \\
29 \pm 25 \% \text {; mean } \\
\text { SCORTEN } 2.5\end{array}$ & $\begin{array}{l}\text { - CsA } 3 \mathrm{mg} / \mathrm{kg} / \mathrm{d} \text { for } 10 \text { days, then } \\
2 \mathrm{mg} / \mathrm{kg} / \mathrm{d} \text { for } 10 \text { days, and finally } \\
\text { I mg/kg/d for } 10 \text { days (24) } \\
\text { - Supportive care (20) }\end{array}$ & $\begin{array}{l}\text { Relative mortality benefit } \\
\text { of CsA (SMR 0.42) over } \\
\text { supportive care (SMR I.02) }\end{array}$ \\
\hline $\begin{array}{l}\text { Mohanty et } \\
\text { al, } 2017^{22}\end{array}$ & $\begin{array}{l}\text { Retrospective } \\
\text { case series }\end{array}$ & 28 & India & $\begin{array}{l}\text { Mean total BSA } \\
35.95 \pm 20.33 \% \\
\text { mean } \\
\text { SCORTEN } 2.05\end{array}$ & $\begin{array}{l}\text { - CsA } 5 \mathrm{mg} / \mathrm{kg} / \mathrm{d} \text { in three divided doses } \\
\text { for } 10 \text { days, along with supportive } \\
\text { care (19) } \\
\text { - Supportive care (9) }\end{array}$ & $\begin{array}{l}\text { SMR of CsA group }(0.32) \\
\text { nearly } 3.3 \text { times lower than } \\
\text { the only supportive treatment } \\
\text { group ( } 1.06)\end{array}$ \\
\hline $\begin{array}{l}\text { Rajaratnam } \\
\text { et al, } 2010^{23}\end{array}$ & $\begin{array}{l}\text { Retrospective } \\
\text { case series }\end{array}$ & 21 & UK & $\begin{array}{l}\text { Mean total BSA } \\
44 \% \text {; mean } \\
\text { SCORTEN } 3.1\end{array}$ & $\begin{array}{l}\text { - CsA IV } 2.5-4 \mathrm{mg} / \mathrm{kg} / \mathrm{d} \text { for } 3-5 \text { days (3) } \\
\text { - IVIg } 0.4-1.0 \mathrm{~g} / \mathrm{kg} / \mathrm{d} \text { for } 3-7 \text { days (I } 4) \\
\text { - Cyclophosphamide } \\
\text { IV } 2.5 \mathrm{mg} / \mathrm{kg} / \text { for } 3 \text { days (2) }\end{array}$ & $\begin{array}{l}\text { Corticosteroids did not } \\
\text { appear beneficial compared to } \\
\text { IVIg or CsA }\end{array}$ \\
\hline $\begin{array}{l}\text { Reese et al, } \\
2011^{9}\end{array}$ & $\begin{array}{l}\text { Retrospective } \\
\text { case series }\end{array}$ & 4 & USA & $\begin{array}{l}\text { Mean total BSA } \\
35.8 \% ; \text { mean } \\
\text { SCORTEN I. } 25\end{array}$ & $\begin{array}{l}\text { - CsA } 5 \mathrm{mg} / \mathrm{kg} / \mathrm{d} \text { in two divided doses } \\
\text { for } 5 \text { days to a month (4) }\end{array}$ & $\begin{array}{l}\text { CsA is efficacious with rapid } \\
\text { response and re-epithelization. } \\
\text { Short-term use of CsA did } \\
\text { not have adverse reactions or } \\
\text { increased infections }\end{array}$ \\
\hline $\begin{array}{l}\text { Singh et al, } \\
2013^{11}\end{array}$ & $\begin{array}{l}\text { Retrospective } \\
\text { case series }\end{array}$ & II & India & $\begin{array}{l}\text { Mean total BSA } \\
23.4 \pm 16.3 \% \\
\text { mean } \\
\text { SCORTEN I. } 45\end{array}$ & $\begin{array}{l}\text { - CsA } 3 \mathrm{mg} / \mathrm{kg} / \mathrm{d} \text { in three divided doses } \\
\text { for } 7 \text { days, then } 2 \mathrm{mg} / \mathrm{kg} / \mathrm{d} \text { in two } \\
\text { divided doses for another } 7 \text { days (II) }\end{array}$ & $\begin{array}{l}\text { Faster re-epithelization, } \\
\text { shorter hospital stay and } \\
\text { relative mortality benefit of } \\
\text { CsA over corticosteroids. } \\
\text { CsA was also well tolerated } \\
\text { by all the patients }\end{array}$ \\
\hline $\begin{array}{l}\text { Szepietowski } \\
\text { et al, } 1997^{24}\end{array}$ & $\begin{array}{l}\text { Retrospective } \\
\text { case series }\end{array}$ & 3 & Poland & Not specified & $\begin{array}{l}\text { - CsA 8-10 mg/kg/d for }|0-2| \text { days and } \\
\text { corticosteroids (3) }\end{array}$ & $\begin{array}{l}\text { Combined and monotherapy } \\
\text { with CsA appear superior } \\
\text { to monotherapy with } \\
\text { corticosteroids. CsA is } \\
\text { beneficial for TEN patients }\end{array}$ \\
\hline $\begin{array}{l}\text { Valeyrie- } \\
\text { Allanore } \\
\text { et al, } 2010^{25}\end{array}$ & $\begin{array}{l}\text { Open, Phase } \\
\text { II trial }\end{array}$ & 29 & France & $\begin{array}{l}\text { Mean total BSA } \\
12.2 \pm 8.2 \% ; \text { mean } \\
\text { SCORTEN } 1.27\end{array}$ & $\begin{array}{l}\text { CsA orally through NG tube, } \\
1.5 \mathrm{mg} / \mathrm{kg} \text { twice daily for } 10 \text { days, } \\
\text { then I mg/kg twice daily for } 10 \text { days, } \\
\text { and finally } 0.5 \mathrm{mg} / \mathrm{kg} \text { twice daily for } \\
10 \text { days (29) }\end{array}$ & $\begin{array}{l}\text { CsA was well tolerated; } 26 \\
\text { out of } 29 \text { patients completed } \\
\text { the I-month treatment. Lower } \\
\text { than expected mortality and } \\
\text { disease progression observed }\end{array}$ \\
\hline
\end{tabular}

Note: *Expression of concern by journal editor and staff over possible data irregularities.

Abbreviations: BSA, body surface area; CsA, cyclosporine; IV, intravenous; IVIg, intravenous immunoglobulin; NG, nasogastric; SCORTEN, SCORe of toxic epidermal necrosis; SJS, Stevens-Johnson syndrome; SMR, standardized mortality ratio; TEN, toxic epidermal necrolysis. 


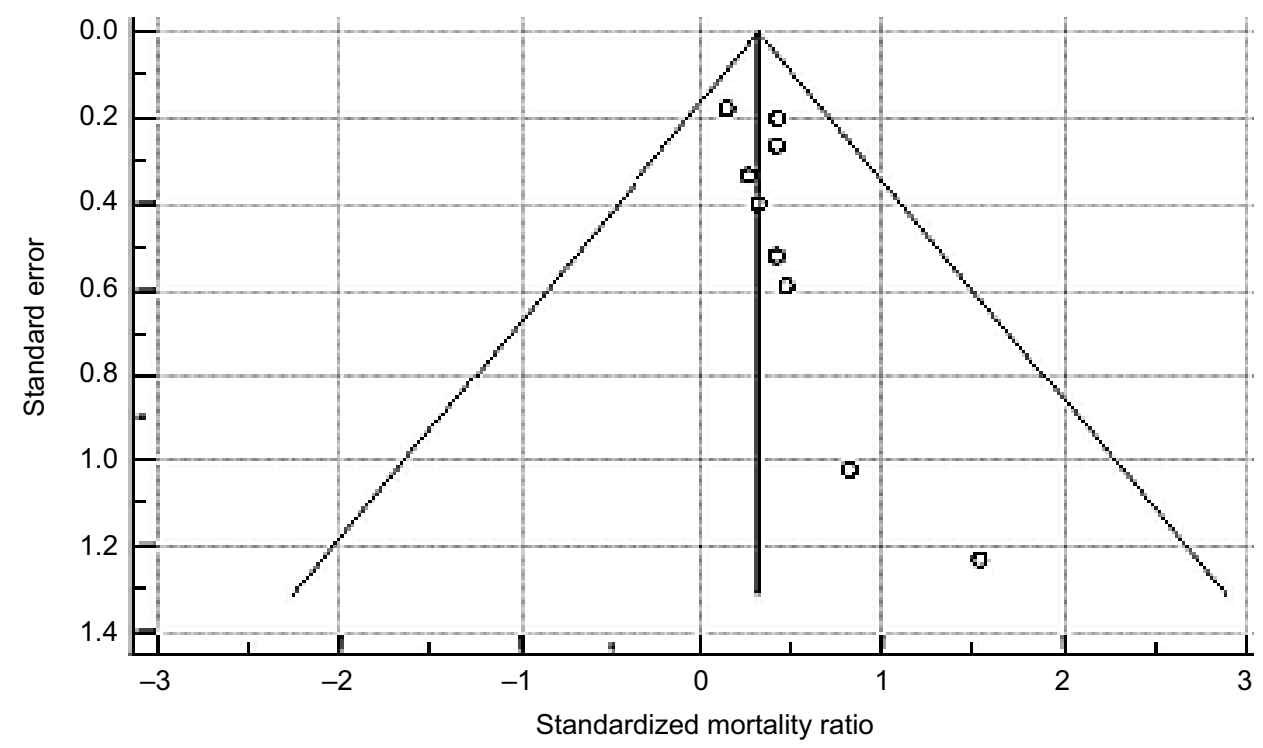

Figure 2 Funnel plot (with pseudo $95 \%$ confidence limits) to assess publication bias; Egger test for publication bias=0.75I, $95 \% \mathrm{Cl}=0.0 \mathrm{I} 46-\mathrm{I} .488, \mathrm{P}=0.0467$.

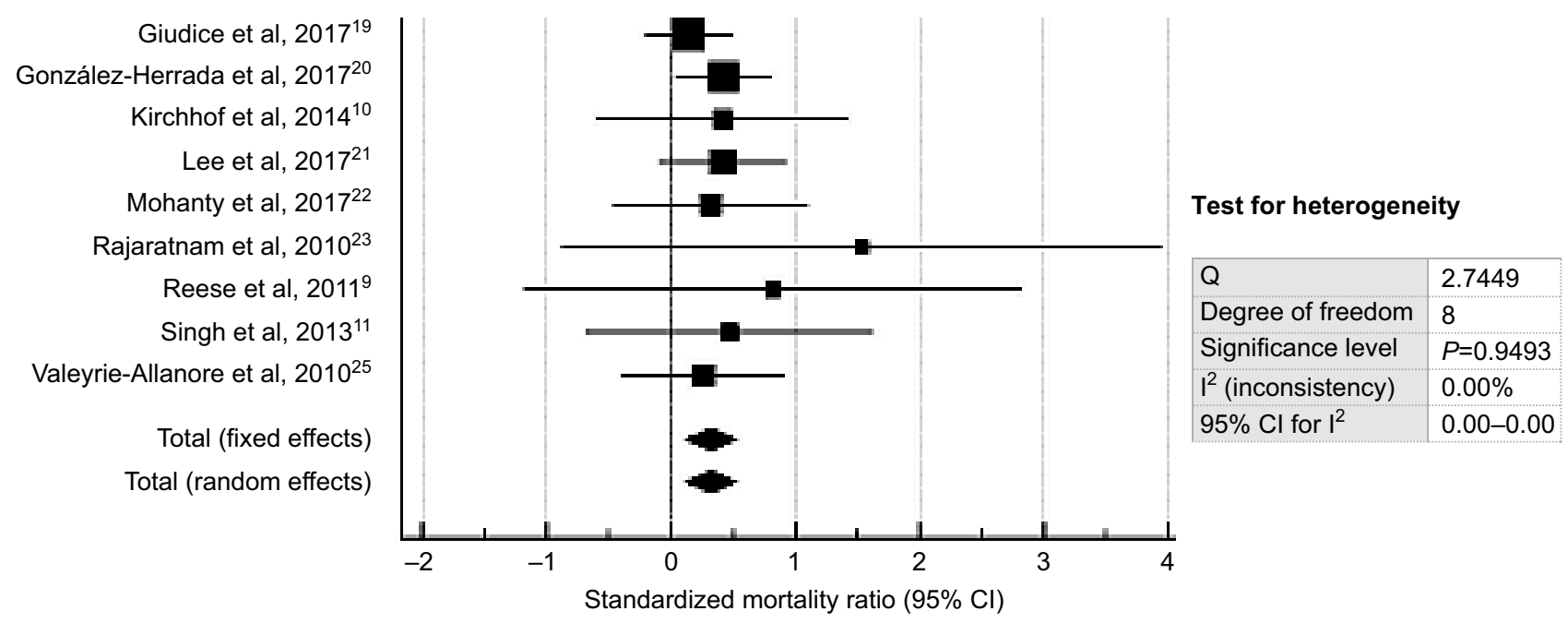

Figure 3 Forest plot showing the standardized mortality ratio and $95 \% \mathrm{Cl}$ of studies on cyclosporine therapy.

distribution of studies (Figure 2) and Egger test was significant for publication bias $(P=0.0467)$.

The meta-analysis found that CsA use was associated with improved mortality in SJS/TEN patients as the pooled SMR was 0.320 (95\% CI: $0.119-0.522 ; P=0.002)$. The forest plot is shown in Figure 3. Fixed- and random-effects analyses yielded similar results.

\section{Discussion}

Almost all of the studies reviewed, support the mortality benefits of CsA therapy for SJS/TEN patients. The pooled SMR was 0.320 (95\% CI: 0.119-0.522; $P=0.002$ ), indicating the mortality benefit of CsA in SJS/TEN treatment. In our meta-analysis, only one study ${ }^{23}$ found slightly increased mortality risk with CsA treatment (SMR 1.538, 95\% CI: 1.30-5.08). In this study, the sample that received CsA was limited to three patients. One patient survived and there was an initial favorable effect with evidence of reepithelialization of the skin in one of the patients who died. It is worth mentioning that the patient had a background medical history of alcoholic hepatitis and encephalopathy. SCORTEN predicted mortality rate was 1.3 deaths, whereas the actual mortality rate after 3-5 days of IV CsA 2.5-4 $\mathrm{mg} / \mathrm{kg} / \mathrm{d}$ was two deaths.

Our findings were concordant with the results of an earlier meta-analysis, ${ }^{14}$ which reported mortality benefit 
for CsA when compared to supportive care (OR: 0.1, 95\% CI: 0.0-0.4). However, the OR was based on a single trial of $\mathrm{CsA}^{25}$ and calculated using an exact logistic regression model. Our meta-analysis thus significantly strengthens the evidence supporting the use of CsA in SJS/TEN patients.

Current understanding of the pathophysiology and mechanisms underlying SJS/TEN remains incomplete, due to the rarity of the condition and lack of a reliable animal model for investigation. ${ }^{26}$ It is presumed that apoptosis is the key mechanism underlying keratinocyte death in SJS/ TEN. Cytotoxic T cells are activated by a culprit drug, which releases granulysin. ${ }^{27}$

The best rationale for using CsA in SJS/TEN is that cytotoxic $\mathrm{T}$ cells destroying epithelial cells are drug-specific and HLA class I restricted, like effector cells in acute graft rejection or acute graft-versus-host disease. ${ }^{7}$ Fas ligand is unlikely a pathogenic mechanism. If it were, IVIg would be useful and would be considered instead of CsA. It is predominantly T/NK with granulysin. ${ }^{27}$

The observed clinical benefits of CsA for SJS/TEN patients could stem from its mechanism of action. It is an immunosuppressive agent targeting the calcineurin complex. The activation of the calcineurin complex, following T-cell receptor activation, results in dephosphorylation of the nuclear factor of activated T cells (NFAT), leading to its migration into the nucleus and binding with its intranuclear counterpart. The resultant complex is a transcription factor for inflammatory cytokines such as interleukin (IL-2). CsA binds to cyclophilin thereby, preventing the dephosphorylation of NFAT and subsequent downregulation of IL-2. ${ }^{28}$ This leads to a consequent decrease in the number of CD4+ and CD8+ (cytotoxic) $\mathrm{T}$ cells in the epidermis, which are key mediators involved in the pathogenesis of SJS/TEN. ${ }^{29} \mathrm{CsA}$ has also been shown to inhibit TNF- $\alpha$ production. ${ }^{29}$ TNF- $\alpha$ is another key cytokine involved in the amplification of apoptotic pathways implicated in SJS/TEN.

CsA, however, is not without its own inherent set of drawbacks. Contraindications to its use include patients with severe renal disease, severe infections, or internal malignancy. ${ }^{30}$ While common adverse effects of CsA are nausea, hypertension, nonmelanoma skin cancer, renal dysfunction, hyperlipidemia, headache, and tremors. ${ }^{31}$ However, it was extremely encouraging that cyclosporine was generally well tolerated in most of the trials and case series, even though these patients were often critically ill., ${ }^{9,11,12}$

The limitations of the current meta-analysis should also be discussed. First, the funnel plot and Egger test $(P=0.0467)$ showed some likelihood of publication bias.
Future meta-analysis should include non-English studies and grey literature as some trials may have been missed in the search process. There is also a risk of bias inherent to the reanalyses of the same case series examined in earlier meta-analyses. ${ }^{14,20}$ Second, there was a paucity of studies examining the use of cyclosporine in SJS/TEN patients, and no randomized controlled trials on the subject exists. This is perhaps not unexpected given the rarity and life-threatening nature of the SJS/TEN. Practically, the possibility of conducting a rigorous double-blind, placebo-controlled trial to study the use of CsA in SJS/TEN patients is remote. Larger case series may be the feasible step forward to help support or refute current evidence. This could be achieved through collaborative effort by tertiary hospitals in keeping a registry of SJS/TEN cases treated with CsA, meticulously documenting the clinical course (including adverse effects) of these patients. Last but not least, another important area for future research concerns the use of cyclosporine in special patient populations, for example, those with HIV/ AIDS, preexisting renal or liver disease, and the elderly (especially those with polypharmacy). The use of CsA in patients with HIV infections is still debated and limited data exist. ${ }^{32}$

\section{Conclusion}

CsA use was associated with improved mortality in SJS/ TEN patients, with a pooled SMR of 0.320 (95\% CI: $0.119-0.522, P=0.002)$ based on nine studies and a total of 256 SJS/TEN patients. Case series, retrospective studies, and an open, Phase II trial have documented its efficacy, safety, and beneficial effects in SJS/TEN patients. A rigorous double-blind, randomized trial would be necessary to confirm its efficacy. However, this may be challenging to achieve given the rarity and life-threatening nature of SJS/ TEN. International effort in collating larger case series may be the feasible step forward to help support or refute current evidence.

\section{Acknowledgment}

This research did not receive any specific grant from funding agencies in the public, commercial, or not-for-profit sectors.

\section{Author contributions}

Qin Xiang Ng conceived, designed, and carried out the study and the relevant data analysis and interpretation. Michelle Lee Zhi Qing De Deyn, Nandini Venkatanarayanan, and Collin Yih Xian Ho carried out the study and the relevant data 
analysis and interpretation. Wee-Song Yeo contributed to the data analysis and interpretation. All authors contributed toward data analysis, drafting and revising the paper and agree to be accountable for all aspects of the work.

\section{Disclosure}

The authors report no conflicts of interest in this work.

\section{References}

1. Harr T, French LE. Toxic epidermal necrolysis and Stevens-Johnson syndrome. Orphanet J Rare Dis. 2010;5(1):39.

2. Abe J, Umetsu R, Mataki K, et al. Analysis of Stevens-Johnson syndrome and toxic epidermal necrolysis using the Japanese adverse drug event report database. J Pharm Health Care Sci. 2016;2(1):14.

3. Bastuji-Garin S, Rzany B, Stern RS, et al. Clinical classification of cases of toxic epidermal necrolysis, Stevens-Johnson syndrome, and erythema multiforme. Arch Dermatol. 1993;129(1):92-96.

4. Schwartz RA, McDonough PH, Lee BW. Toxic epidermal necrolysis: Part I. Introduction, history, classification, clinical features, systemic manifestations, etiology, and immunopathogenesis. JAm Acad Dermatol. 2013;69(2):173-e1.

5. Schneider JA, Cohen PR. Stevens-Johnson syndrome and toxic epidermal necrolysis: a concise review with a comprehensive summary of therapeutic interventions emphasizing supportive measures. Adv Ther. 2017;34(6):1235-1244.

6. Locharernkul C, Loplumlert J, Limotai C, et al. Carbamazepine and phenytoin induced Stevens-Johnson syndrome is associated with HLAB* 1502 allele in Thai population. Epilepsia. 2008;49(12):2087-2091.

7. White KD, Chung WH, Hung SI, et al. Evolving models of the immunopathogenesis of T cell-mediated drug allergy: the role of host, pathogens, and drug response. J Allergy Clin Immunol. 2015;136(2):219-234.

8. Schwartz RA, McDonough PH, Lee BW. Toxic epidermal necrolysis: Part II. Prognosis, sequelae, diagnosis, differential diagnosis, prevention, and treatment. J Am Acad Dermatol. 2013;69(2):187-e1.

9. Reese D, Henning JS, Rockers K, et al. Cyclosporine for SJS/TEN: a case series and review of the literature. Cutis. 201;87(1):24-29.

10. Kirchhof MG, Miliszewski MA, Sikora S, et al. Retrospective review of Stevens-Johnson syndrome/toxic epidermal necrolysis treatment comparing intravenous immunoglobulin with cyclosporine. J Am Acad Dermatol. 2014;71(5):941-947.

11. Singh GK, Chatterjee M, Verma R. Cyclosporine in Stevens-Johnson syndrome and toxic epidermal necrolysis and retrospective comparison with systemic corticosteroid. Indian J Dermatol Venereol Leprol. 2013;79(5):686.

12. Kuma P, Kanti Das N. Cyclosporine in toxic epidermal necrolysis: a brief review of the emerging therapeutic modality. Dermatol Online $J$. 2016;22(10).

13. Méndez A, Monforte V, Berastegui C, et al. High intra-individual variability of cyclosporine pharmacokinetics in lung transplant recipients without cystic fibrosis. Clin Transplant. 2014;28(6):743-748.

14. Zimmermann S, Sekula P, Venhoff M, et al. Systemic immunomodulating therapies for Stevens-Johnson syndrome and toxic epidermal necrolysis: a systematic review and meta-analysis. JAMA Dermatol. 2017;153(6):514-522.
15. Fouchard N, Bertocchi M, Roujeau JC, et al. SCORTEN: a severityof-illness score for toxic epidermal necrolysis. J Invest Dermatol. 2000;115(2):149-153.

16. Guegan S, Bastuji-Garin S, Poszepczynska-Guigné E, et al. Performance of the SCORTEN during the first five days of hospitalization to predict the prognosis of epidermal necrolysis. $J$ Invest Dermatol. 2006;126(2):272-276.

17. Arévalo JM, Lorente JA, González-Herrada C, Jiménez-Reyes J. Treatment of toxic epidermal necrolysis with cyclosporin A. JTrauma Acute Care Surg. 2000;48(3):473-478.

18. Firoz BF, Henning JS, Zarzabal LA, Pollock BH. Toxic epidermal necrolysis: five years of treatment experience from a burn unit. $J \mathrm{Am}$ Acad Dermatol. 2012;67(4):630-635.

19. Giudice G, Maggio G, Bufano L, et al. Management of toxic epidermal necrolysis with plasmapheresis and cyclosporine A: our 10 years' experience. Plast Reconstr Surg Glob Open. 2017;5(2):e1221.

20. González-Herrada C, Rodríguez-Martín S, Cachafeiro L, et al. Ciclosporin use in epidermal necrolysis is associated with an important mortality reduction: evidence from three different approaches. J Invest Dermatol. 2017;137(10):2092-2100.

21. Lee HY, Fook-Chong S, Koh HY, et al. Cyclosporine treatment for Stevens-Johnson syndrome/toxic epidermal necrolysis: retrospective analysis of a cohort treated in a specialized referral center. $J$ Am Acad Dermatol. 2017;76(1):106-113.

22. Mohanty S, Das A, Ghosh A, et al. Effectiveness, safety and tolerability of cyclosporine versus supportive treatment in Stevens-Johnson sndrome/toxic epidermal necrolysis: a record-based study. Indian $J$ Dermatol Venereol Leprol. 2017;83(3):312.

23. Rajaratnam R, Mann C, Balasubramaniam P, et al. Toxic epidermal necrolysis: retrospective analysis of 21 consecutive cases managed at a tertiary centre. Clin Exp Dermatol. 2010;35(8):853-862.

24. Szepietowski J, Wassik F, Szybejko-Machaj G, Maj J. Toxic epidermal necrolysis successfully treated with cyclosporin. Report of three cases. J Eur Acad Dermatol Venereol. 1997;9(2):169-172.

25. Valeyrie-Allanore L, Wolkenstein P, Brochard L, et al. Open trial of ciclosporin treatment for Stevens-Johnson syndrome and toxic epidermal necrolysis. Br J Dermatol. 2010;163(4):847-853.

26. Stern RS, Divito SJ. Stevens-Johnson syndrome and toxic epidermal necrolysis: associations, outcomes, and pathobiology - thirty years of progress but still much to be done. J Invest Dermatol. 2017;137(5): 1004-1008.

27. Chung WH, Hung SI, Yang JY, et al. Granulysin is a key mediator for disseminated keratinocyte death in Stevens-Johnson syndrome and toxic epidermal necrolysis. Nat Med. 2008;14(12):1343-1350.

28. Amor KT, Ryan C, Menter A. The use of cyclosporine in dermatology: part I. J Am Acad Dermatol. 2010;63(6):925-946.

29. Remick DG, Nguyen DT, Eskandari MK, et al. Cyclosporine A inhibits TNF production without decreasing TNF mRNA levels. Biochem Biophys Res Commun. 1989;161(2):551-555.

30. Lebwohl M, Ellis C, Gottlieb A, et al. Cyclosporine consensus conference: with emphasis on the treatment of psoriasis. JAm Acad Dermatol. 1998;39(3):464-475.

31. Palestine AG, Nussenblatt RB, Chan CC. Side effects of systemic cyclosporine in patients not undergoing transplantation. Am J Med. 1984;77(4):652-656.

32. Jacobson SK, Calne RY, Wreghitt TG. Outcome of HIV infection in transplant patient on cyclosporin. Lancet. 1991;337(8744):794. 


\section{Publish your work in this journal}

The Journal of Inflammation Research is an international, peer-reviewed open access journal that welcomes laboratory and clinical findings on the molecular basis, cell biology and pharmacology of inflammation including original research, reviews, symposium reports, hypothesis formation and commentaries on: acute/chronic inflammation; mediators of inflammation; cellular processes; molecular mechanisms; pharmacology and novel anti-inflammatory drugs; clinical conditions involving inflammation. The manuscript management system is completely online and includes a very quick and fair peer-review system. Visit http://www.dove press.com/testimonials.php to read real quotes from published authors.

Submit your manuscript here: https://www.dovepress.com/journal-of-inflammation-research-journal 